\title{
From postcoloniality to decoloniality, from heritage to perpetuation
}

\section{The Islamic at the museum}

\author{
Wendy Miriam Kural Shaw
}

The Sassanian Emperor Anoushirvan once went hunting with his vizier. They rode their fine steeds through lush woods and sunny vales. Eventually they came to a clearing no less full of birdsong than the woods, full of beautiful buildings lying tragically in ruin. Two owls sat on a broken vault. The emperor turned to his trusted advisor and, knowing that he understood the language of the birds, asked him what they were saying.

'Forgive me, my king, for I will only convey what I hear with no balm for your ears', said the vizier. Curiosity overtook pride as the emperor agreed to lay anger aside.

The younger owl has asked the hand of the daughter of the older owl. This father-in-law is shrewd: requesting a dowry, he asks no more than one ruined town, a perfect kingdom for owls. Yet his son-in-law is shrewder. He says: 'if the king maintains his careless rule, I will give you a thousand towns such as this!'

Anoushirvan wept as they departed. In the following years, the justice of his rule won him glory. And to think, it came all from the wisdom of owls, sitting where hens should have roosted (Würsch, 2005, p. 281).

What do we learn? Representation remedies absence. It invents the very malady that it aims to cure.

The notion of representing 'the Islamic' presumes an externally definable and thereby absent entity called 'Islam'; that this 'Islam' might achieve presence through some action, such as the presentation of objects, performances or lectures; and that this presence would accrue added value beyond that of 'Islam' itself. This desire to re-present Islam structures the nature of its representation. If we conceive of Islam solely as an engagement with or a making present of the divine, then individual prayer would suffice. Perhaps we would need a place for the bowing to the divine, $s-j-d^{1}$, essential to the embodied ritual of Islamic prayer; perhaps we would need a place for the congregation of such bowing, the $m-s-j-d$.

Yet this is not the type of making present to which we refer when speaking of museums or heritage. This making present relies on a disembodiment, a bringing together of products surrounding the $s-j-d$, to which they may or may not be related. What is made present at the museum is not the greeting, $s-l-m$ implicit in Islam itself - the greeting of the divine, which also constitutes peace - so much as the greeting of its by-products, a hall of mirrors in which the verbal noun of 


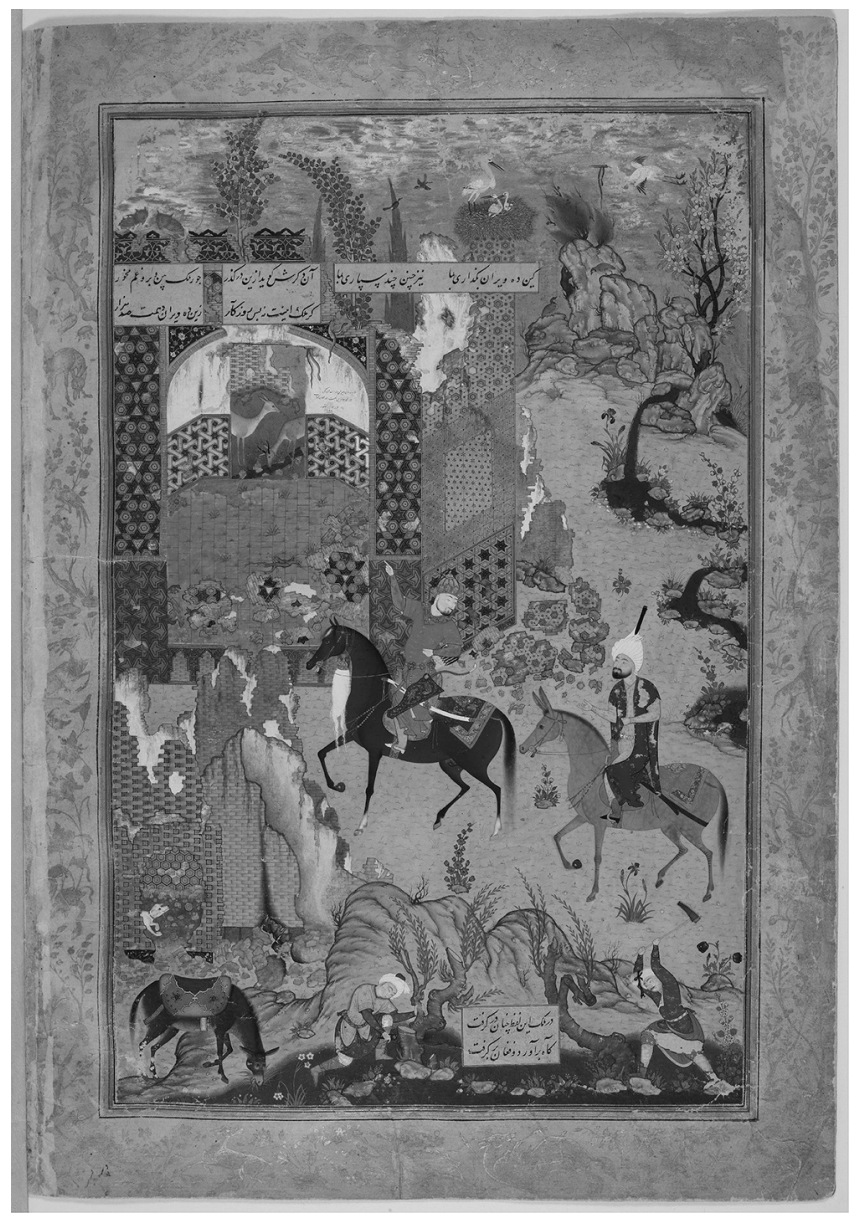

Figure I.I Mirak the painter, 'Anoushirvan and the Owls', Khamsa-i Nizami, British Library OR 2265, f. I5v. (1539-1540).

greeting the divine is not there. ${ }^{2}$ This slippage, from the embodied act of greeting the divine towards representing the act in its by-products, centralises the worldliness (the secularity) of the museum. The making-present structurally repeats and underscores absence, rendering the 'unfortunate marionette that the history of the unheeded subaltern must unfold', by separating the misapprehension of darstellung as vertreten (Spivak, 1999, p. 259).

What does it mean to represent Islamic heritage in the museum? The very question undermines its possibility. Islamic thought refuses the distinction at the core of the museum: the premise that Islam is elsewhere. Islam cannot be reconstituted from its by-products in a passive construction, where the by-products are made to fit into a pre-existing matrix of making meaning. Rather, if Islam is to genuinely 
inhabit the museum, it can only emerge if these by-products actively bring forth their intrinsic expressions of Islam. This paper will argue that despite the best of intentions, the drive towards heritage preserves the coloniality of collection within the post-coloniality of heritage. It reproduces the marginalisation of Islam that it attempts to cure. Instead, this essay proposes a model of perpetuation that draws on Islamic concepts of embodied knowledge, resonating with those articulated by Plato, to enable tangible and intangible entities of Islamic culture to articulate Islam by constructing their own matrices of meaning.

\section{With the best of intentions: from coloniality to post-coloniality}

What do we do with the mess that the nineteenth century bequeathed to us? Capitalism, industrialisation, racism, resource depletion, globalised inequity... and folded in all that, the legacy of rapacious materialism enshrined in the museum. Do we just give everything back? That has been the call for some time now: to return the booty of colonialism lingering in museums to its rightful owners... After all, the logic of public display in glorified warehouses no longer functions as well in an era of virtual access, social distancing, and an absence of leisure time. But what will they do when the objects are returned? It is not like the people over 'there' have the time and space that we lack. It is not as though they haven't been creating living cultures in the meantime. We may be able to give things back across space, but not across time. If you stole something from my great grandmother and return it to me, I may want it. I may also very well have no use for it. Once a thief, always a thief. Once we wrest objects out of the processes of life, they acquire new life in new processes. ${ }^{3}$ There is no redemption.

The museum houses an afterlife, as Theodor Adorno famously pointed out in his 1955 essay, 'The Valery Proust Museum’:

The German word, 'museal' ['museumlike'], has unpleasant overtones. It describes objects to which the observer no longer has a vital relationship and which are in the process of dying... Museums are like the family sepulchers of works of art. They testify to the neutralization of culture... Once tradition is no longer animated by a comprehensive, substantial force but has to be conjured up by means of citations because 'It's important to have tradition', then whatever happens to be left of it is dissolved into a means to an end... That the world is out of joint is shown everywhere in the fact that however a problem is solved, the solution is false.

(Adorno, 1967, p. 175)

This world is out of joint in that it continually murders objects to manufacture meaning out of them, transforming mourning into pleasure (Crimp, 1987).Adorno's rendering the near homonymy between museum and mausoleum depends on a negativity surrounding death, which Adorno identifies as particularly German, one that refrains from enacting life in the present tense in favour of embalming it in the 
fixed form of tradition. Nonetheless, this all is as it should be: as long as death remains inevitable, museums allow for resurrection.

The museums will not be shut, nor would it even be desirable to shut them. The natural-history collections of the spirit have actually transformed works of art into the hieroglyphics of history and brought them a new content while the old one shriveled up... The only relation to art that can be sanctioned in a reality that stands under the constant threat of catastrophe is one that treats works of art with the same deadly seriousness that characterizes the world today.

(Adorno, 1967, p. 185)

The museum that Adorno monumentalises functions as a family sepulchre where death is the condition enabling recognition and where culture becomes suspended in the everlasting life(lessness) of knowledge. Objects lie securely in crypts or in hermetically sealed cases, each a Snow White awaiting a prince destined to never arrive. In this suspension, she becomes less herself than a metonym of the family be it nation or other genus of category - with which she lies. Here or there, interment remains constant; once dead, repatriating the body fails to revive the dead. In this model, those of us who work with museums all serve as undertakers. We freshen up corpses, comfort the bereaved, and write eulogies for the public. But what to do if we are not German, and the museal mausoleum lacks the same ring? Will we play the emperor for whom all is already in ruins, or will we play the canny vizier who teaches us that a living city is worth more than a sublime ruin?

Ironically (or perhaps typically) for a place tasked with keeping things, the roots of the modern museum lie in a gaping absence. The Museum of Alexandria was destroyed in the fourth century CE. By the time the word was revived in sixteenth to eighteenth century Europe:

The Musaeum was a vanished object (nothing to see) yet still a voluptuous memory (much to know); it was not a collection of things but a body of scientific and literary knowledge.

(Lee, 1997, p. 186)

It was as imaginary as it was anachronistic. 'Until the final decade of the eighteenth century', Paula Young Lee points out, “'museum” was a means of knowing rather than a place for showing; it was a transitive process of thought rather than a given collection of things' (Lee, 1997, p. 186). It was a cabinet of scholars, not things; a place of direct discourse rather than an indirect discourse established between objects metonymic relationships with absences like artists, histories, cultures or nations.

Yet objects, previously inhabiting esoterically organised private studios and cabinets, were quick to creep into museums where the concept of art neutralised the ideologies that objects had originally inhabited. Established in 1796, the Musée des antiquités et monuments français collected the fragments of royal tombs and church architecture in order to exhibit them through a historical and chronological 
framework (Greene, 1981). As a partisan of classicism in the perennial debate between the ancients and the moderns, Antoine Chrisostome Quatremère de Quincy, future secretaire perpétuel ('director in perpetuity' as of 1816) of the Académie des Beaux Arts was a vociferous opponent to this transformation of the concept of the museum into a warehouse for art. Referring to the Napoleonic plunder of palaces and cities for objects of European art, he explained:

In vain do we convince ourselves that the antiquities taken from [Rome] today can preserve their virtue. Everywhere else they are sterile, since everywhere else they lack the power deriving from their place; everywhere else they are disenchanted. They become images for which there is no mirror.

(Ruprecht, 2014, p. 413)

While bemoaning this spatial and spiritual incarnation of the object, Quatremère articulated the metonymic attribution at the heart of every valuation of an object beyond its materials or its commodified status: its capacity to serve as an image of that perceived as absent. In his very complaint that displacement severed the object's tie with meaning, he underscored the object's apparent capacity to convey meaning transparently across time. In situ, an object carried with it the values of a place; it was a history, a place of remembrance. Yet even as Quatremère naturalised the capacity of the object to transport meaning across time, he bemoaned its incapacity to convey meaning across space. The museum was not so much a graveyard as a collection of gravestones. Even as many of the objects collected under the Napoleonic expeditions in Europe were returned, many from his farther-flung forays - particularly Egypt - remained. Already images across the vector of time, objects also became images across the vector of territory. Each object mapped onto a system of knowledge constituting a world unto itself, an encyclopaedia safely detached from the physical realities it purported to represent.

The emerging institution of the museum depended on normalising the destruction of the organic situation of the object through a new emplacement depending on the subterfuge of preservation in a matrix of disembodied knowledge conceived as universal. This ideology of abstracted aestheticism governed by a temporo-spatial matrix consciously neutralised preceding hegemonic ideologies of royalty and religion. Museums became a purgatory for objects, suspended between their living relationship with the vagaries of the human and their death and degradation into oblivion. There, objects released from their initiating situation (and any accompanying signification) were at liberty to be resituated in a new matrix of signification. Like the word 'museum' itself, plucked from antiquity as a space of scholarly gathering and plopped into modernity as a space of gathering things, the institution of the museum granted objects liberty from their origins only on the condition of enslavement to a new regulatory matrix.

The persistent coloniality intrinsic to the post-colonial museum, whether located in imperial centres or post-colonial nation-states, emerges not simply the ownership of the objects or the location of the exhibitions, but in the procedures that give objects order. It begins with the distinctions of meaning that structure 
institutions, keeping some objects and destroying others, differentiating between types of collections, designating some as museums, some as rich people's bunkers, and others as zoos. It continues with the distinctions of value that place some objects on view and others in storage (Brusius \& Singh, 2017). It continues with the matrices of knowledge that give meaning to the objects. Finally, it gains narrative through the spatial organisation that favours one vector of meaning over others in the matrix as visitors move through a collection.

This matrix of knowledge is embodied, of course, in the types of information we foreground on the label.

(a) Name of maker

(b) Name of object

(c) Date

(d) Location of production

(e) Material

(f) Dimensions

(g) Provenance

(h) Location in collection (accession number)

(i) Narrative information (description of object and commentary)

Each of these information types constitutes a vector. Curators construct exhibitions through the complex task of foregrounding one or two of these vectors over the other. In the nineteenth century, Islamic art was shuttled into museums of craft and rich men's bunkers, but not into zoos or museums of art. Organised by material (e), carpets and tureens alike metonymically articulated a distinct realm visually identifiable as 'Islamic', but with no expectation that the exotic should articulate culture. In the early twentieth century, some works gained value through tropes such as art, science, or material culture, shifting the vector of meaning from that of materiality (e) to that of maker or patronage (a), objects became metonyms for a vector of historicity (c). Comparisons of similar instances of the same object or illustration have enabled narratives based on the name of the object (b), often with a synoptic narration of the work itself (i). In the postcolonial framework following World War II, interest in material legacies of modern nation-states foregrounded geography (d). With the rise of critical postcolonialism, increasing concerns about the role of the museum in making meaning have enabled trends in acknowledging modern collectors and institutions as signifying actors in constructing Islamic arts, leading to the possibility of turning the endeavour of a pure history of the Islamic world through objects on its head, resulting instead in the possibility of exhibitions foregrounding the history of collection and acquisition $(\mathrm{g} / \mathrm{h})$. These enable fascinating histories of collection and effectively underscore the problematic nature of the museum itself. A fanciful exhibit might invite aesthetic appreciation of particular colours, introducing another vector $(j)$; yet another might look to historical representations of topics (k), like gender, astrology, or science. Yet each imposes a categorical episteme external to the objects on display. 
Conceived through structural linguistics, each object functions as a signifier in a chain of signifiers. Each relates to its neighbours associatively, producing meaning through lateral connections enabled through these vectors of meaning. Each object is not only unique but also syntagmatically replaceable - another object exists, somewhere, that could approximate similar information; collections become enriched as each of the objects necessary to tell an associative narrative are filled in. For example, the Bernisches Historisches Museum owns a small collection of 'Oriental' works, largely donated by the wife of Henri Moser (1844-1923), who had collected objects while travelling with the Russian army during its conquest of Central Asia.

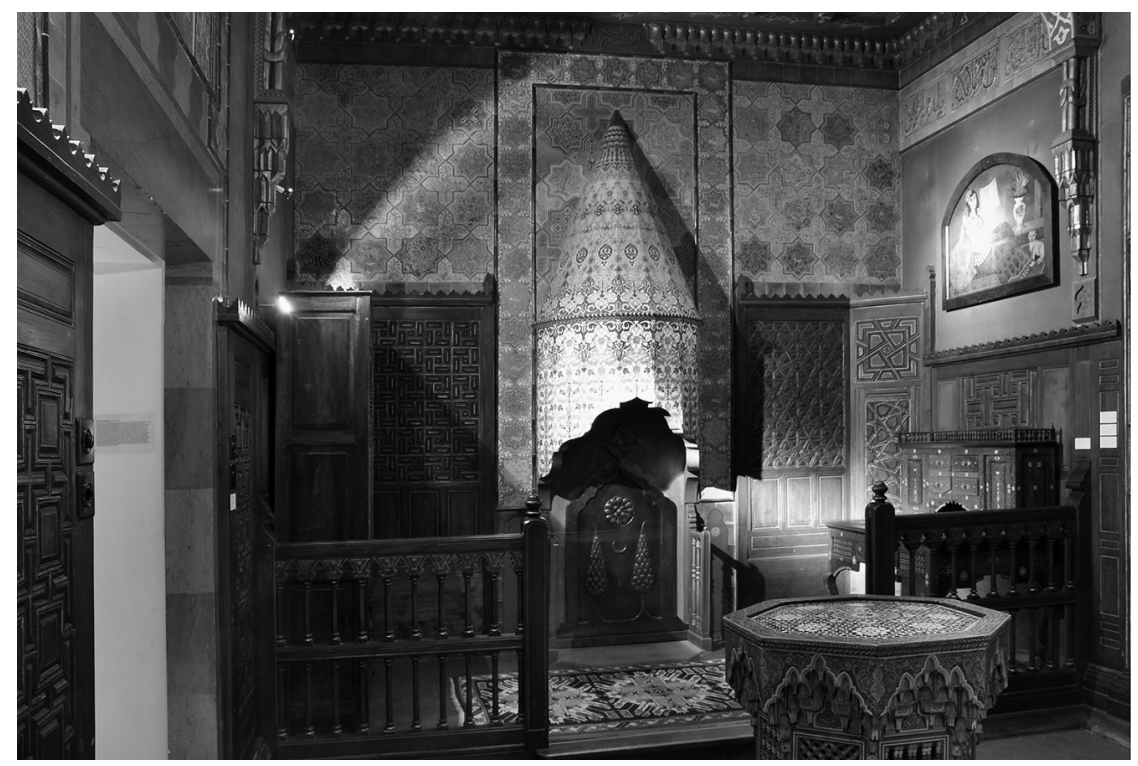

Figure I.2 Henri Moser Collection, Bernisches Historisches Museum.

While many of these works cohabit an eclectic room recreating his itinerant exhibitions, others populate a small auditorium next door. At my visit in 2012, objects were arranged in cases around a square room, with one case devoted to keys hanging in mid-air, and another to scimitars. Leading the visitors clockwise around the room, a museum volunteer illustrated the nineteenth-century Qur'ans on display with the story of the seventh-century emergence of Islam.Although the objects, the most famous of which include lacquered pen cases and barbers' instruments typical of the Qajar era, illustrate layered histories of colonialism in Central Asia, her narrative conformed to a predetermined history. The artifice of the story of 'Islamic art' perhaps needs no more evidence than the consistency of the narrative that can be applied to almost any collection, anywhere in the world, regardless of the diverse contexts of creation and amalgamation of the collections. Islam, however diverse from within, becomes reduced to one story when narrated from outside. 
This would be true of any vector informing the narrative between objects. Each episteme imposes our modern questions. Although other types of information persist, they fall by the wayside through the process of narrative implicit in the curatorial structure of exhibition. In bringing the object to life, they restrict as much as enabling its speech. I ask my vizier, what are the birds saying?

The ruins are too beautiful.

We fall into the trap of ruination.

\section{Platonic perpetuation}

The logic of the museum, rooted in the notion of heritage, prefers the permanence of objects as inscription to the ephemerality of action as speech. What if the condition of keeping is not that of death, but of perpetuity, of circulation? What if we replace the noun of the object with the verb of its movement through the world?

The Platonic opposition between speech and writing concerns perpetuity, not of the object but of the ineffable that passes through it. It encourages us to pay attention less to the object than to its passage. Although generally not labelled specifically as Platonic, this notion of perpetuation pervades Islamic discourses of maintaining the past within the present. Islamic heritage would emerge through this notion of perpetuity rather than preservation, which depends on death in order to embalm the form as a palimpsest of potentially fluid content. Is it possible to imagine the museal through the model of perpetuity rather than that of preservation? What might this museality look like? What objects would it hold? How would it function?

Platonism exemplifies the epistemic tension between preservation and perpetuation. All too often Plato is hailed as the father of Western philosophy.Yet as a good Athenian, he would have held every non-Greek as a barbarian. There was no West. The man known as Jesus would not be said to be born for another 500 years, and the religion claiming inspiration from his supposed teachings would not gain power for 500 more. At that moment, when Christianity became the law of the land in the Roman Empire, centred no longer in Rome but in Constantinople (because at that time Rome, more concept than place, could be displaced to a new territory, and the old territory could be left behind like so many stones, nothing more than a snake's skin), 1,000-year-old Platonism was exiled: in 529 CE, the Emperor Justinian outlawed all Platonic Schools. Philosophers from throughout the empire found a new home in the Sassanian Empire, which was conquered by Muslim forces in the following century.

This Near Orient (as situated against the region that would later call itself the Occident) was replete with Christians and Jews as well as Muslims. Plato and Socrates settled into the cushions of new symposia, called majlis, where thinkers would sit and debate, and even drink wine (Ahmed, 2015, pp. 57-71). Under Islamic sovereignty in Baghdad, the practice of state-sponsored translation initiated under the Sassanian Empire persisted, leading to the development of libraries not only maintaining antique manuscripts, but also perpetuating them in translation, through commentary, and in new discourses structured by philosophy. Although in 
the ninth century, philosophy was officially banned in Islamic theology, it already pervaded the dialogical systems underpinning Islamic law and continued to circulate through the writings of Muslim intellectuals. The proverbial cat was already out of the bag.

The West distinguished itself from the East through Plato's exile. His thought did not return to the Occident for over five centuries.Antique philosophy came to Europe through the Islamic world, particularly through access to libraries through the conquest of southern Italy and Spain from Islamic rule in the twelfth to thirteenth centuries. Monks read Plato through Christian eyes, which cleansed it of its paganism, its pederasty, its playfulness, its passions. The Islamic world that had preserved the thought of Plato through his exile from Western Christendom was treated strangely like the Virgin Mary, as though it were a vessel through which thought had passed, itself untouched, pure and eternally Other. Yet that Islamic world was more of a mother than a midwife to Platonism, nurturing its passage into a new world.

And Platonism may have been more of a mother than a midwife to the Islamic world as well. Socrates' qualified critique of rhetoric, the Qur'an both condemns $j-d-l$ (the undefined term parallel to sophistry) in general and accepts it when it leads to truth or good conduct. Likewise, argumentation (h-w-r, indicating the exchange of words, and $h-j-j$, indicating argumentation) can be understood as 'a quest of legitimacy of theological dialectics' in early theological disputes (Belhaj, 2012, pp. 265-266). While the translation of surviving Platonic texts occurred later, it is possible that Platonism circulated in the cosmopolitan, multifaith discursive environment of the seventh-century Arabian peninsula where the Qur'an emerged. Regardless of the extent to which Platonism informed aspects of the Qur'an, its presence in the formative years of Islamic law rooted in transregional, trans-temporal practices of disputation. Not only is the Qur'an dialogical in its address towards the believer, a first-person divine voice speaking to a second-person prophet, Muhammad, and through him the believer; but the worldly structure of Islam in the law is also dialogical. The stillness of the written (maktub) exists in perpetuity - past, present, future - not on the plane of creation, but on that of the Divine, in the heavenly tablet that is the original Qur'an. ${ }^{4}$ Like Platonic truth, the Divine is unreachable; every attempt to reach it blinds us, and reaching transcendence is equivalent to death. Life perpetuates that which is written, the reading of which constitutes experience.

Thus Platonism precedes both Christianity and Islam by centuries and diffused into the thought of each differently, although at times interconnectedly. This Plato is not a Western forefather, but a pagan Athenian who toyed with monotheism as much as with the mythologies of other gods. His thought persisted. Where it had died, it was resurrected at various times and places, and in different ways, in several discursive traditions that themselves interacted, quoted, blended, rejected and reflected each other. Platonic thought is like a gas that, although hard to trace, works its ways into the most subtle of corners.

Plato's mouthpiece, Socrates - yes his teacher, but also his puppet, articulating truth with whatever words Plato wrote into his mouth in any given dialogue disputed the existence of the gods, yet articulated his arguments allegorically, 
drawing on myth willy-nilly. He did not even seem to require the pre-existence of myths to transform them into parables, nor did he restrict himself to myths of his own culture, which his listeners might know and therefore believe. The purpose of myths was not the truth of the myth itself, but the message they imparted. In fact, the truth of the message half the time was not even the message itself, but the passage of that message through the litany of questions that challenged it: the very process of the dialogue. The structure of knowledge in Plato's dialogues - the reason they are written as dialogues rather than as treatises or as songs - is that knowledge is not static, but passes through language, back and forth between interlocutors with the elegance of a tennis ball volleyed between rackets. The very opposite of the museum object, held still and safe behind glass, Truth for Plato must repeatedly hold its own with every challenge. Truth is not in the static endpoint of an argument or the form of an object, but in the passage of meaning through ideas as well as through things.

We might compare the relationship between the object and the meanings that pass through it to the relationship Socrates suggests between writing and speech. Contrary to popular simplified misinterpretations, Socrates was not against writing. He knew perfectly well that students like Plato and Xenophon were writing down his words; he even may have edited some of the texts. He was not against it so much as he recognised its danger. Considering a myth from ancient Egypt (which he may not have invented, but for which we moderns have no other evidence), he says that the multitalented god Thoth, inventor of arithmetic, logic, geometry, astronomy and games like checkers and dice put forward the great new idea of writing. Writing is the cousin of logical mathematics, divinatory astronomy and the seedy world of games of chance. Thoth presents his new idea to King Amon as a memory supplement, but the king calls out his trick. He says that writing only promotes forgetfulness, replacing memory with the image of speech. Unlike a teacher, writing cannot talk back. In its failure to defend itself, it transforms wisdom into opinion. Written words can be taken from one place to another, displaced just as I have displaced Plato's text here. Written words are no different from the objects that a museum re-places with other works through processes that obscure their deracination, decapitation, and displacement. You never know with keeping things: writing is a gamble. But what do we have instead? In his know-itall way, Socrates offers an answer:

...when one makes use of the science of dialectic and, taking a fitting soul, plants and sows in it words accompanied by knowledge, which are sufficient to help themselves and the one who planted them, and are not without fruit but contain a seed from which others grow in other soils, capable of rendering that seed forever immortal, and making the one who has it as happy as it is possible for a man to be.

(Plato and Rowe, 2005, p. 65)

The problem, then, is not with the physicality of words, their manifestation as text on paper, but with their passage. Words live on not through quotation, but in 
giving rise to new words: they live in their replanting, in their regeneration, in their capacity for movement. This could indict the text, if only it did not come to us in a text. Socrates does not tell us to burn our books, but to endow them with the living conversation of our minds. Likewise, we are not to destroy our museums, but endow the objects within them with living meaning beyond the categories of the family created in its sepulchre.

These articulations of the Platonic dialectic differ intrinsically from the Hegelian dialectic, upon which much of modern thought - including the structure of historical periodisation and the progress implicit to it - is based. Like Plato, Hegel's understanding of the dialectic rests on the notion of passage. However, for him, the movement in this passage transpires through confrontation and resistance. Each entity emerges through resistance to its precedent, which both moulds the new entity and enables its difference, resulting in a process of improvement conceived as progress. In the Hegelian legacy of the museum, objects produce meaning as representatives of their place in a legacy of coming into being; their own meanings lie dead, because they have been surpassed. Conversely, the perpetuation of the regrown seed (in the parlance of Socrates) or the reinterpreted utterance (hadith, in the parlance of Islamic law) does not endow change with a direction or a necessary will. Change happens, like mutation, but even if driven by will, its results lack direction. It is a model rooted in living regeneration rather than in discarded pasts.

\section{Perpetuation through rearticulation in Islam}

The concern over writing was central in the formative years of Islam, where the sacred voice of God embodied in the Qur'an trembled in the tension between text and sound, written and oral, book and recitation. The Qur'an can be defined through two descriptive practices: the self-description in its own text; and the narration of its delivery to humankind. The Qur'an describes itself as the manifestation of the sacred tablet of creation located on the plane of the Divine, a translation into a linguistic form recognisable to humanity. In this act of translation, the recitation gains both temporality and physicality. That is, whereas the tablet contains its language synchronously - all parts of the Qur'an-as-divine-tablet exist equally in all time and all place. In contrast, language unfolds diachronously, such that the Qur'an-as-text unfolds as we read or recite it. As the manifestation of the Divine will to make itself known, the Qur'an is self-same with all of creation. It is the infinite encyclopaedia, as is creation itself, all of which manifests signs of the Divine to those who know. According to the dominant Sunni interpretive tradition, as a non-created manifestation of the unique Divine, the Qur'an is distinct from but contemporary with the Divine. All of this complexity emerged through centuries of debate entrenched in the discursive tradition of Islamic law, which regenerates itself through rearticulation in the tradition of legal scholarship. Interpretation is not preserved in fixed texts; it is perpetuated through the rearticulation of text in recitation and interpretation.

This emerges most clearly in the praxis of learning the Qur'an, which focuses on memorisation. A fully memorised text distinguishes itself from a written one in 
that the mind presents all aspects of the text as simultaneously available. Only in the process of recall do some aspects of the text progress to articulation. As on the sacred tablet, the Qur'an exists in the mind of the memoriser as continually equipotent. Thus in a tradition that may stretch back to early Islamic traditions, people in the Senegambia region of Africa who have successfully memorised the text are known as 'walking Qur'ans', producing an unbroken chain through the prophet, the angel Gabriel (believed to have delivered the sacred word to the prophet), and ultimately to the divine. Knowledge becomes embodied not only through memorisation but also through the drinking of ink washed from written verses of the text or licking off the revelation from such tablets (Ware, 2014).

The idea of text as a site of perpetuation rather than preservation emerges in the thought of the bibliophile al-Jahiz (776-869), a proponent of philosophical disputation (qalam) during the ninth-century heyday of philosophy in Islamic thought. Just as our era contends with the vast expansion of knowledge enabled by the internet, he enjoyed the florescence of books enabled by the technological revolution of rag paper, far cheaper to produce than preceding substrates for writing, parchment and leather. Yet as in our era, the growth of knowledge production brought new practices of conflict and censorship (Montgomery, 2013, p. 4). Defending the importance of discussion and of books in an era thwarting disputation (the inquisition known as the mihna), he argued:

The composing of books is more effective than building in recording the accomplishments of the passing ages and centuries. For there is no doubt that construction eventually perishes, and its traces disappear, while books handed from one generation to another, and from nation to nation, remain forever renewed.

(Necipoğlu, 1995, p. 38)

What for modern subjects might amount to an argument in favour of keeping books, as in a library, al-Jahiz expresses as an imperative to write them. The notion of books for him is less of a physicality than of a passage for the perpetuation of ideas perennially renewed through composition. The opposition here is not between the monument-as-object and the book-as-text, but between the physicality of an object and the passage of meaning through it. His most famous work, The Book of Living, a seven-volume survey of everything created by God, was composed as a totalising exposition of creation designed to internalise debate in the souls of his readers, thus propagating dialogical practice not simply within books but in the social practice of engaging with them ${ }^{5}$ (Montgomery, 2013, p. 56). Whether intentionally or not, his purpose may have been similar to that of Plato, who probably wrote dialogues attributed to his teacher Socrates in order to preserve the rhetorical tools of democratic speech for an era of mass rule (Allen, 2012).

As in many imperial contexts, rulers in Islamic lands often commissioned encyclopaedic texts, particularly histories, as a means of situating knowledge as part of the centralisation of power and naturalisation of sovereignty (Muhanna, 2018, pp. 87-88). In the Islamic world, the early fourteenth-century Compendium of Chronicles written by Rashid al-Din under the Mongol dynasty, the turn of the 
fifteenth-century Book of Lessons, Record of Beginnings and Events in the History of the Arabs and the Berbers and Their Powerful Contemporaries by Ibn Khaldun written under the Mamluk rule, and the The Gardens of purity in the biography of the prophets and kings and caliphs, by the Persian-language historian Mirkhwand (1433-1498) working under the Timurid dynasty, each renewed this role. Like generations of historians who came after them, each tried to establish a true rendition of events, yet discovered a wormhole of new questions. Tree and seed, followed by tree and seed again and again: each generation creates the entirety of the world anew.

The totalising ambitions of such works invite comparison with the temporally and geographically distinct mid-eighteenth-century Encyclopedia by Denis Diderot and Jean-Baptiste le Rond d'Alembert. Like the Book of Living, the Encyclopaedia aimed to teach everything. 'The goal of an encyclopaedia is to assemble the knowledge scattered far and wide on the surface of the earth, to expose its general system to our fellow men with whom we live and to transmit it to those who will follow us...' (Creech, 1982, p. 183). Its objectives were firmly grounded in the mortal over the immortal, in knowledge as tangible rather than as indicator of the ineffable. If the totalising goals of the Book of Living placed al-Jahiz in the uncomfortable, potentially blasphemous, position of emulating God's exposition of all creation in the Qur'an in the attempt to praise it, the totalising goals of the Encyclopaedia granted potential omniscience to every reader. Although Diderot was well aware that the Encyclopaedia was not complete in its present form, its ultimate ideal was that of a potentially comprehensive compendium. In contrast to al-Jahiz's ambition to impress dialogical practice upon his readership, the Encyclopaedia aimed to give power to its readers through a thorough listing of what and how human knowledge enables the processes of the world. Whereas for al-Jahiz, creation served as a transient medium for the contemplation of the divine; for the Encyclopaedia, materiality itself was the end product of knowledge. This was distinct from the tradition in the Islamic world, where like al-Jahiz, centuries later, Mirkhavand put more faith in history writing than in buildings, subject to ruin.

Buildings may be seen
Ruined by sun and rain.
Erect history's strong foundation
To escape from wind, rain, and desolation.

(Necipoğlu, 1995, p. 38)

Many more examples (and possible counter-examples) would be necessary to argue for either a wholesale enactment of Platonism in Islamic thought, or for a pervasive preference for the perpetuation of the word over the permanence of matter throughout the vast corpus of Islamic texts. Rather, what the above examples suggest is a mode of distinguishing between modern notions of preservation, invested in maintaining the object, and notions of perpetuating thought frequently found in both Platonic and Islamic discourses. The modern Islamic scholar Mohammad Arkoun articulates a similar distinction between the anthropological definition of tradition as 'the sum of customs, laws, institutions, beliefs, rituals, and 
cultural values which constitute the identity of each ethno-linguistic group', which he likens to the use of ' $u r f$ in Islamic law, as legitimised by the usuli methodology of jurists, which perennially rearticulates the sunna, the tradition of the prophet as articulated in word (hadith) and deed (Arkoun, 2003, p. 22). Tradition is not simply the sum total of what exists in Islam, but that which circulates through the law. Naturally, this process of rethinking is itself subject to debate, as truth lies not in the conclusion but in the capacity to speak back to challenges.

\section{From preservation towards perpetuation}

If we are to imagine an Islamic heritage that derives from Islamic thought - not a heritage of the Islamic world, but a concept of heritage that is Islamic - then how can we envision a site that emphasises perpetuation over preservation? If we have come to imagine a museum as a materialisation of a totalising book like the Encyclopaedia, then how might we conceive of a museum rooted in the totalising knowledge of the Qur'an, or al-Jahid's Book of Living that honours it? What kind of muses would dance in it, inspiring what kinds of relationships with knowledge, with the human, or with Truth? Can the museum as mausoleum come to house not as a crypt of dead objects but a celebration of perpetuation?

Each of these forms of heritage messaging coincides with a particular set of premises and objectives. The former, which I provisionally call objective heritage preservation, presumes that there is a distinct and identifiable set of elements that constitutes Islam that can be identified and set within a matrix that corresponds to the sets that establish the norms and boundaries of other parallel sets, whether constituted by similar religious categories or other types, such as geographical or temporal categories often also indicated through the overarching category of 'Islam', particularly in art history. The latter, which I call embodied heritage perpetuation, engages in a decolonisation of the category of Islam by recognising it as perpetually productive of its identity through a continual reconstruction of the past with an eye to the future. As Shahab Ahmed articulates: 'something is Islamic to the extent that it is made meaningful in terms of hermeneutical engagement with Revelation to Muhammad as one or more of Pre-text, Text, and Con-text' (Ahmed, 2015, p. 405). If, contrary to the modern premise of the museum, all knowledge is understood as indivisibly related to revelation - even when not directly about cosmology, agency, prayer or other matters understood to directly impinge on the Divine, an Islamic premise asserts that all we can know is always already part of Truth. This proves an awkward reality for a universalist desire for an unmarked, unmediated and undenominational truth. Yet to deny it also imposes an episteme which occludes that which it seeks to understand.

Embodied heritage production articulates identity multivalently, resisting the pragmatic stability enabled by objective heritage preservation. Whereas the former emphasises transcultural communication at the potential cost of reductive summary, the latter emphasises cultural expression at the cost of transcultural communication. Each mode of heritage messaging has its own pragmatic and theoretical limits, and each enactment of heritage presentation - such as that which might take place within a ritual, at a musical performance or in a museum - must negotiate 
between the poles of objective heritage preservation and embodied heritage perpetuation, recognising the real world constraints of social expectations, need, and range of address. In other words, all heritage messaging needs a bit of the mausoleal to give it a semblance of stability, but the cemetery of culture need not be a place of death. Rather, it can recognise the uncanny livingness of the space of remembrance that embodies us simultaneously in past and future.

Between the poles of heritage preservation and perpetuation, Islam as a living entity encounters several hurdles of modernity: its scripturalisation into a discourse pitting authentic roots against inauthentically multivalent practices through nineteenth-century Orientalist philology and religious studies; its segregation as historicised tradition from a progressive, secular world through premises reliant on protestant modes of religious privatisation under colonialism and during the twentieth-century establishment of postcolonial nation-states (Tageldin, 2011); and its subsequent illiberalisation through governmental efforts at decolonisation in the late twentieth and early twenty-first centuries, resulting in a strong coincidence between restrictive, authoritarian governance and Islamism. In response to all of these framings of Islam, heritage messaging floats as though folded in a bottle from elsewhere: an object example (whether intangible or tangible heritage) of cultural practices that precede and/or persist through these phases framing the production of a recognisable set of practices called 'Islam', both confirming and contravening its limits. One way or the other, the exposition of heritage provides a window to another world. Yet this window requires a frame with a critical approach to the epistemology of modernity, including its framings of Islam. As Muhammad Arkoun points out:

'Islamicizing knowledge' must be preceded by a radical epistemological critique of knowledge at the deepest level of its construction as an operative system used by a group in a given social- historical space. We need to differentiate ideological discourses produced by groups for assessing their own identity, power and protection, from ideational discourses, which are controlled along the socio-historical process of their elaboration in terms of the new critical epistemology.

(Arkoun, 2003, p. 23)

Aiming to represent Islamic heritage in institutions like museums, objective heritage preservation runs the risk of reifying oppositions between 'us' and 'them', identifying Islam with modern communities even as it locates Islam as a non-actor in a mythic past. It preserves forms - material and immaterial - at all costs, including the cost of the potential plurality of meanings that have transited through the object over time and place. The preserved object becomes a vessel not of ideational but of ideological discourses. This may objectively preserve the object, but effectively destroys the modes of knowledge that it embodies. Only through the perpetuation of meaning can the object have a substrate through which to survive. It turns out that the opposite of destruction is not preservation; rather, they are all too often synonyms in which preservation uses the object as a mimetic shroud for that 
which has been destroyed. The opposite of destruction is perpetuation; and if the object survives alongside thought in that perpetuity, all the better.

To this end, we can produce a mode of engagement with the forms of culture in which, rather than organisation into precedent categories, objects articulate knowledge. Samer Akkach describes a longstanding Islamic paradigm in which aesthetic practices function not as outlets of emotion, but as modes of knowing alongside those of philosophy, mathematics, and natural sciences, all of which share a shared goal of apprehending the truth of the Divine (Akkach, 2019, pp. xx-xxi). To the extent one might speak of an 'eye of the beholder', this is not an individual subjectivity governed by desire, but a subjectivity informed by a broad range of embodied aesthetic and intellectual practice.

The key to the shift from preservation towards perpetuation lies in enabling objects to instruct on their own terms and situating them so that their teachings inform each other. Rather than knowledge functioning as a descriptive practice that imposes order on objects, it becomes a productive practice in which objects articulate themselves. The objective becomes less to tell a predetermined story rooted in one of the vectors of meaning described above, but one that enables objects to articulate narratives imparting knowledge on multiple vectors. The recipient of the narratives encounters them less as learning about than as learning from the Other, expanding their own set of expressive tools.

The purpose of the exhibition shifts from placing the object in a pre-existing order, representing an external episteme (system of knowledge), into a revelation of its intrinsic epistemes. The meaning of the painting above shifts from an exemplary status as 'Persian' painting and the rarity of the signature (located on the vault, like graffiti) - art historical concerns - towards engagement with the poetic nexus referenced by the image, touching on multiple narratives implicit but not articulated in the text. This is readily apparent in the inclusion of a second story with a woodcutter at the bottom of the frame, which would have enhanced the meaning of the image and the poetic text associated with it within a broader cultural landscape. The image also invites comparison with architectural forms from the region, and with other texts with the same characters, such as the Fables of Kalila and Dimna. The image is not simply an illustration of an epic poem, but a focal point in a broader literary discourse.

If objects are to represent a culture, we need to engage with them with a broad knowledge of that culture on multiple levels. We need to let the objects articulate their elements as they would to a viewer in that culture, whose concerns would probably be less about cultural influence or authorship, less about the date or geography, and more about how justice functions in the righteous world, and how to live their own lives as elites viewing these manuscripts. We can and should situate these works in their temporogeographic matrix, but we cannot substitute that act of taxonomic placement for knowledge of the culture. We can, of course, look to the histories of collection of these objects, which often wrest the painting from the book, underscoring the process of cut-and-paste which renders the works of one culture as reflections of the rapacious entitlement of another. But to do so is not to speak of Islamic culture as such, but rather as a metonym of its appropriation and 
reconceptualisation as knowledge of the other embodied both in Orientalism and in the museum.

Islamic heritage emerges through this process of appropriation, but if we are to engage with a heritage that is Islamic, it must enable objects to articulate their worldview in the plenitude of their intellectual and lived cultural traditions. We need to be able to learn from them, just as a subject in the sixteenth century would have.

This learning from initiates an alternative set of practices. Rather than just describing works, what if our own artistic creation comes to embody and reflect them? What if the idea of heritage becomes dislocated from identities and origins? What if what has happened with the hegemony of European art as a global contemporary expressive practice were to be taken out of the ghetto of regional heritage or 'world music' and also become a globalised expressive praxis? This embodiment of knowledge might become the greatest function of the museum: a mediator of that which is brought to life through the crumbled ruin or the mausoleum.

\section{Making collections Islamic: matrices of decoloniality}

On the level of the exhibition, this involves a breakdown of the categories through which we conceive of objects and offer them meaning through exhibition. It can only begin in a theoretical form, in the way that we write narratives about objects in the liberty of text, where we are not bound by entrenched physical boundaries such as ownership, insurance companies, and curatorial departments. But reality often begins in theory, so here goes: what might a collection that articulates its intrinsic knowledge rather than representing external vectors of knowledge look like?

My recent work articulates a decolonial model for art history, in which the subject position of the individual changes depending on the episteme from which they perceive. As though staring at an isometric, polyhedral, intertwining and laterally infinite Islamic pattern, the placement of the viewing subject remains mobile between a modern episteme of geohistoricity and an Islamic episteme of awareness of Truth via divine order (Shaw, 2019, pp. 326-335). What kind of exhibition structure induces or reflects this mode of apprehension?

The question of exhibition organisation is essentially mathematical. How do we organise sets into series, and deploy them across space temporalised through our movement? The dominant model functions through a logic of linear similitude along a single vector. Ideally, each object or object group follows the next through a pattern of difference along a single vector. For example, a retrospective of a single artist (rare in Islamic art) follows the category a (name of artist), generally through the vector c (time). Many exhibitions of Islamic art follow a dual vector of time in the form of dynasty (c) and geography (d), articulating the category of Islam as a historically hegemonic practice of sovereignty. How can we envision an alternative?

Let us return to the Henri Moser room at the Bernisches Historical Museum, where objects exist in visual association, but have complete syntagmatic freedom in terms of time or date. This is a free association of objects, shocking against an 
ordering system predisposed to art history. Yet most of us live amid such cacophony, inhabiting environments in which objects beside each other do not 'match', but coexist. Such a room reproduces an idealised 'image' of the Orient, a fantasy still explicitly tied to the Thousand and One Nights on the museum's website. ${ }^{6}$ Could this unique, eclectic collection function to inform an exhibition of 'Islamic art' as a site of knowledge production, perhaps just as well as the linear exposition of totalising collections in large museums? If so, how could it manage this task?

Assuming that each object functions against other objects syntagmatically, then there is no reason to assume that the association between objects must always follow a single vector. Consider the children's game of Dobble. It consists of 55 cards, each with 8 of 57 symbols. Seemingly magically, the math works out such that every pair of cards has one and only one match of symbols. ${ }^{7}$ In the game, the player who calls out the match first wins the pair. The one with the most pairs wins (my daughter never lets me win). Winning aside, what if each of these symbols were one of our vectors, so some objects match in terms of (a), and others in terms of (b), then others in terms of (c). As in any exhibition, a given object tells a story in relation to its companion, but the vector of the relationship is both arbitrary and variable. Knowledge emerges less through linear narration than through the circular building of repeated elements. Curiosity leads from one vector to another, such that the fifth time the visitor encounters a vector, she comes to recognise it, calls it out, wins. Rather than being pushed into a pre-existing order, the objects thus become deployed to speak specific aspects of their stories against a shifting parade of neighbours. The condition of the exhibition would not be the consistency of a single vector (the overarching narrative of the exhibition), but the ability of objects to articulate aspects of their presence associatively through syntagmatic placement. Just as a decolonial art history requires decentring of the subject potentially modelled on Islamic pattern, this embedding of the object in a matrix of shifting vectors enables an awareness of the object's multiple, simultaneous, shifting, and decentred subjectivities. An expanded array of mathematical premises informing exhibition strategies suggests ordering systems no less objective, and perhaps more dynamically informative, than the tried and true convention of linearity along a single unchanging vector.

Such a strategy of multiple contextualisations necessitates multimedia formats. It recreates the fascination of the nineteenth-century Oriental room but imbues it with the same type of associative meaning we might experience in the variety of our own complex material lives. Thus, for example, the Qajar-era Qur'an mentioned above functions in a context of Central Asia, Russian colonialism, trade with Iran, and the legacy of the Qur'an itself. It might indicate vectors of paper paint production, thus legacies of fabrication and trade. These might link to the rise of photography, or the industrialisation of carpets. A single work could syntagmatically rub elbows with entities representing each and all of these relationships objects as well as literary quotations, music, films, reproductions and artworks reflecting on these legacies. We are no longer limited by the material legacies of collections and the media and quality classifications that have structured them. The only limit is the stories we want to tell. 


\section{In perpetuity: living}

The crumbling building at the centre of the painting of Anoushirvan and his minister teems with life. As they fall away, the stability of the isometric patterns covering the vault enables productive flourishing. The owl, after all, is getting married. The storks are feeding a young family. Snakes, mice, deer and birds frolic in pairs. Delicately, even botanically, rendered flowers flourish. Much as we experience in the Corona times that I write this essay, nature flourishes in the absence of humans.

Likewise, the cemetery teems with life. Trees grow tall, vines flourish, mice, birds and foxes forage. Mosquitos eat me alive. People tend their small plots in remembrance. Recitations float across the air. We mourn the dead, but uncannily we live on. They live on in us. If museums can manage to live as vitally as mausoleums, this may not be such a bad thing.

The perpetuity of inheritance is simple, and it works like this. My daughter's lips are the same as my lips, which are the same as my father's lips, which are the same as his father's lips, with a far larger lower than upper lip, both of which are full and not very wide. At an age when she was young enough that nonexistence was both not far and absolutely incomprehensible, she asked me repeatedly where her grandpa, who died a year and a half before her birth, was now. 'Far away', I said. 'Too far even to Skype?' she said. Every day she asked again. One day I said: 'He is in our lips, and every time we kiss each other, we kiss him'. She was satisfied.

\section{Notes}

1 Arabic words are formed from groups of (usually three) consonants, indicating a concept around which a variety of nouns, verbs and adjectives evolve. The vowels imposed through speech change in various dialects and languages. I indicate the radicals rather than the words to emphasize the conceptual aspect of language and to avoid the pitfalls of transliteration that artificially emphasizes one vocalization as normative.

2 'Islam' of course is generally translated as 'submission', which is not incorrect as much as incomplete. In English, the notion of submission suggests force against the will of the subject.This is, rather, the kind of willing submission involved in recognition of the good will of the other, a laying down of arms and defenses implicit in the act of greeting. I like to think less of human greetings than of how a dog lays down and shows her belly, which can function as submission to a greater power (as with another dog), but also as a willingness to recognise the love of the other and enjoy a nice belly rub.

3 This essay considers the material object, but can also be considered regarding objects with tangential relationships with materiality (related to but not equivalent with intangible heritage), such as food, music, or dance, deployed as conveyors of identity.

4 Although Islam understands the unique Divine as identical with that of other Abrahamic traditions and the word Allah is used by Christians, Jews and Muslims alike, the word God in English implies a more anthropomorphic concept. In Islam, the Divine is likened to a veiled, self-perpetuating light, located closer than the believer's own jugular vein, and is endowed with some anthropomorphic descriptors (a face, hands and feet), but no necessary embodiment.

5 Montgomery convincingly argues that the title, normally translated as the Book of Animals and partly informed by Aristotle's Naturae Animalia, refers instead to the condition of living occurring in the afterlife as mentioned in the Qur'an, and pertaining to animals, humans and to the supernatural creations, angels and djinn. 
6 https://www.bhm.ch/en/exhibitions/permanent-exhibitions/oriental-collectionhenri-moser/ Accessed 16.04.2020.

7 This is, of course, not magic. It follows the logic of a finite projective plane of order 57. Dobble relies on a condition that is not true in its prospective exhibitionary application: in the game, for any two symbols, there is one and only one card containing those symbols. This is not true with objects, for which many symbols - region, artist, date and material - may well overlap. It may be that these are 'mute' signifiers in our imaginary game, much like color in the card game - signifiers that may coincide, but offer little meaning for the connections we are interested in making.

\section{References}

Adorno, T.W. (1967). Prisms. (S. Weber \& S. Weber, Trans.). London: Neville Spearman.

Ahmed, S. (2015). What is Islam? Princeton, NJ: Princeton University Press.

Akkach, S. (Ed.). (2019). Ilm: Science, religion and art in Islam. Adelaide: University of Adelaide Press.

Allen, D. (2012). Why Plato wrote. Hoboken, NJ:Wiley-Blackwell Publishing.

Arkoun, M. (2003). Rethinking Islam today. The Annals of the American Academy of Political and Social Science, 558, 18-39.

Belhaj, A. (2012). Dialectics of the Qur'ān through Q 2:258. Islamic Studies, 51(3), 263-273: 265-266.

Brusius, M., \& K. Singh. (2017). Museum storage and meaning: Tales from the crypt. New York: Routledge.

Creech, J. (1982). 'Chasing after advances': Diderot's Article 'Encyclopedia'. Yale French Studies, 63, 183-197.

Crimp, D. (1987). The end of art and the origin of the museum. Art Journal, 46(4), 261-266.

Greene, C. M. (1981).Alexandre Lenoir and the Musée des Monuments Français during the French Revolution. French Historical Studies, 12(2), 200-222.

Lee, P.Y. (1997). The Musaeum of Alexandria and the formation of the Muséum in eighteenth-century France. The Art Bulletin, 79(3), 385-412.

Montgomery, J. (2013). Al-Jahiz: In praise of books. Edinburgh: Edinburgh University Press.

Muhanna, E. (2018). The world in a book: Al-Nuwayri and the Islamic encyclopedic tradition, Princeton, NJ: Princeton University Press.

Necipoğlu, G. (1995). The Topkape scroll: Geometry and ornament in Islamic architecture. Los Angeles, CA: Getty Center Publications.

Plato (2005) Phaedrus. (C. Rowe, Trans.). London: Penguin Books.

Ruprecht, L. A. (2014). Religion, classical utopias, and the French Revolution:The strange career of a revolutionary classicist in the strange course of a French Revolution. Soundings: An Interdisciplinary Journal, 97(4), 405-431.

Shaw, W. M. K. (2019). What is 'Islamic' art? Between religion and perception. Cambridge: Cambridge University Press.

Spivak, G. (1999). A critique of postcolonial reason: Toward a history of the vanishing present. Cambridge: Harvard University Press.

Tageldin, S. M. (2011). Secularizing Islam: Carlyle, al-Sibā ${ }^{-} 1$, and the translations of 'religion' in British Egypt. PMLA, 126(1), 123-139.

Ware, R.T. III (2014). The walking Qur'an: Islamic education, embodied knowledge, and history in West Africa. Chapel Hill, NC: University of North Carolina Press.

Würsch, R. (2005). Nizami’s Schatkammer der Genheimnisse. Weisbaden: Reichert Verlag. 